\title{
Altitudinal zonation of vegetation in the Padang region, West Sumatra, Indonesia
} \author{
Hiroyuki WatanABE ${ }^{8}$

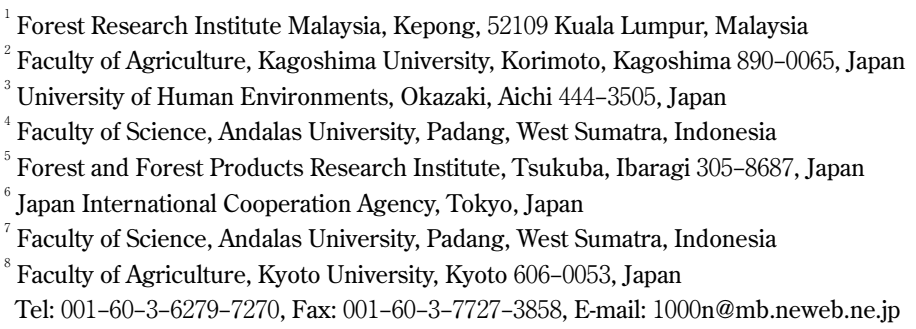

Sen Nishimura ${ }^{1}$, Tsuyoshi Yoneda ${ }^{2}$, Shinji Fujir ${ }^{3}$, Erizal MukhtaR ${ }^{4}$, Hisashi Abe ${ }^{5}$, Daisuke Kubota ${ }^{6}$, Rusjdi Tamin ${ }^{7}$ and $^{2}$

ABSTRACT The altitudinal gradient of vegetation of the Barisan range in a coastal region near Padang, West Sumatra, was studied in 10 plots (0.1-6.55 ha) distributed from 600 to $1780 \mathrm{~m}$. Trees with a diameter at breast height of more than $10 \mathrm{~cm}$ were employed for classification of the vegetation. Four vegetation zones, two types of montane and two types of lowland vegetation, were recognized based on cluster analysis, floristic information, and the physiognomy of these forest stands. An upper zone of montane vegetation (Lower montane Fago-Myrtaceous forest) was distinguishable from a lower zone (Sub-montane Fago-Myrtaceous forest) due to the remarkable dominance of several species of Fagaceae and Myrtaceae, and its lower canopy height. The two zones of lowland vegetation (Upper hill dipterocarp forest and Mid-hill dipterocarp forest) were distinguishable by their species composition of Dipterocarpaceae and stratification of the stand. The altitudinal zonation corresponded well with classic zonation patterns previously reported for West Malesia, but the critical threshold altitudes were lower in comparison with those in other regions. The borderline between the lowland and montane vegetation, corresponding to a Kira's warmth index of $\mathrm{WI}=180{ }^{\circ} \mathrm{C} \cdot$ month, was around $200 \mathrm{~m}$ lower in Padang than in other regions of West Malesia, and the critical altitude between the two zones of lowland vegetation was also around $300 \mathrm{~m}$ lower in Padang than on Mt. Kinabalu. The characteristics of altitudinal zonation in Padang were discussed with reference to the climatic features of this region, namely, the low temperature and hyperhumidity.
Key words: depression of border altitudes, Dipterocarpaceae, Fagaceae, hyperhumid climate, hill forest, montane forest, Myrtaceae, warmth index, West Malesia

\section{INTRODUCTION}

The altitudinal zonation of vegetation in West Malesia, west of Wallace's line, was previously divided into different formation types based on vegetation structure and physiognomy (Burtt Davy, 1938; Symington, 1974; Richards, 1996; Wyatt-Smith, 1963; Burgess, 1969). Below around $3000 \mathrm{~m}$ above sea level (asl), three types of forest formation are commonly recognized; namely, lowland rainforest, and lower and upper montane rainforest. Generally, the lowland rainforest is represented by Dipterocarpaceae, while the higher altitudes forests are characterized by montane representatives such as Fagaceae, Lauraceae, Myrtaceae and Theaceae, and the absence of Dipterocarpaceae. The average temperature at the border between lowland and montane forests is 20 ${ }^{\circ} \mathrm{C}$, being equivalent to the latitudinal climatic boundary conditions between subtropical and warm temperate climates according to Kira's Warmth Index (WI $=180$ ${ }^{\circ} \mathrm{C} \cdot$ month, Kira, 1976). The above mentioned studies denote that the major component of mountain vegetation in Malesia changes from Dipterocarpaceae to Fagaceae at this boundary climate.

Previous studies in Sumatra have shown equal dominance of Fagaceae and Dipterocarpaceae in hill forests at an elevation lower than $800 \mathrm{~m}$ asl (Ogino et al., 1984; Hotta, 1986 \& 1992; Hotta et al., 1989; Laumonier, 1997). Moreover, according to Richards (1996), the actual altitudinal ranges of zonation differ considerably 
depending on the rate of changes of climate factors; namely, temperature, atmospheric humidity, wind velocity and radiation, along an altitudinal gradient. This information suggests that compared to other Malesia regions, a different pattern of altitudinal zonation perhaps exists around the Padang region of West Sumatra because of its prominent hyperhumid climate. There are, however, very few studies concerned with altitudinal zonation in Sumatra (Ohsawa, 1982 \& 1995; Ohsawa et al., 1985, Laumonier, 1997). Moreover, to date, no quantitative studies including the hill dipterocarp forest zone have so far been published.

This study therefore aims to evaluate the altitudinal gradient of original vegetation below $2000 \mathrm{~m}$ asl in the Padang region of West Sumatra. We first clarify the climatic features then define the altitudinal zonation of West Sumatra. Next, we compare altitudinal zonation among other regions in West Malesia. Finally, we analyze the main characteristics of altitudinal zonation in West Sumatra with reference to the climatic features of this

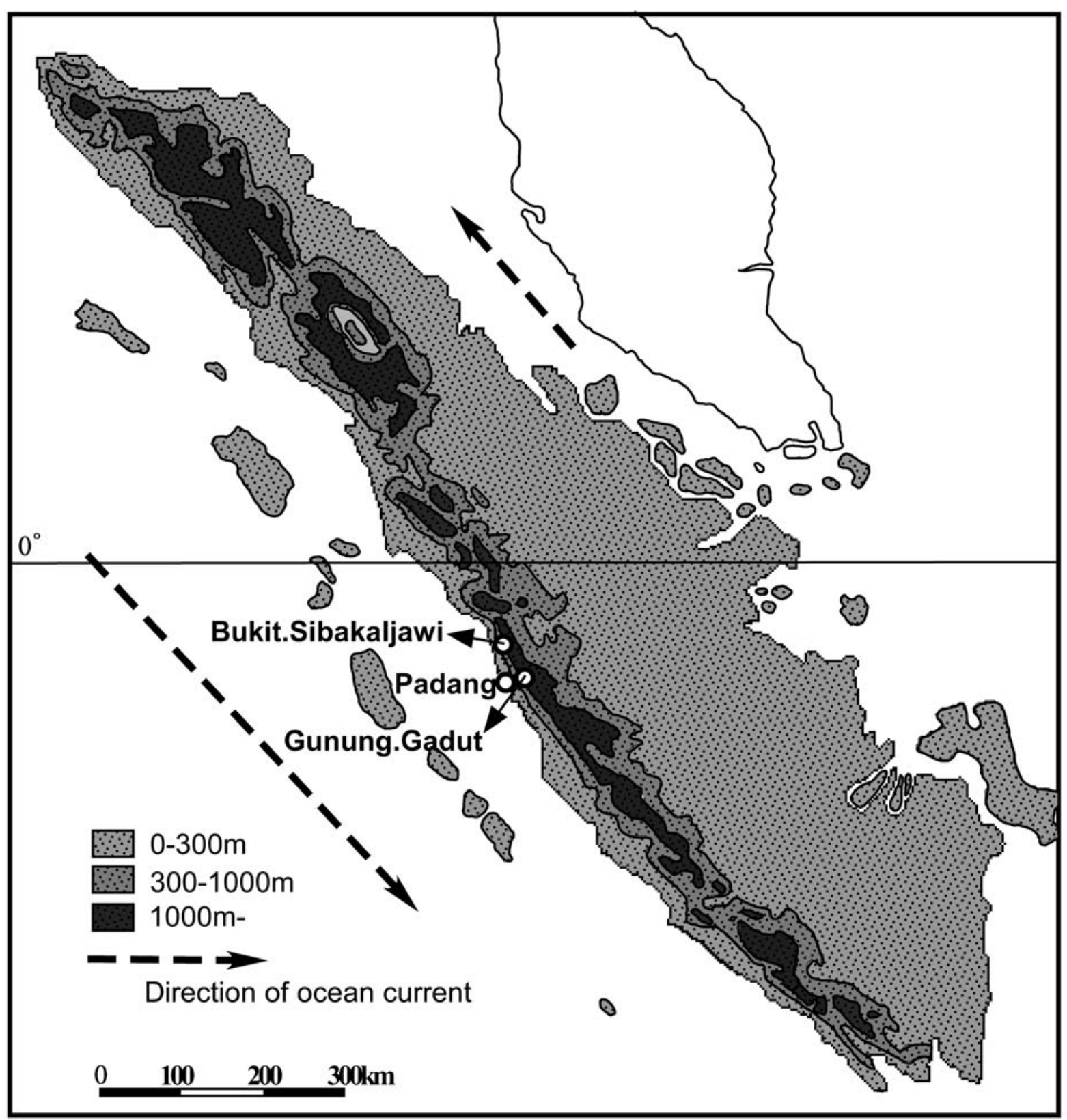

Fig. 1. Topography map of Sumatra (revised after Laumonier (1997)) and the location of the two study mountains. Three different altitudinal zones are shown in different colors. Broken arrows show the direction of the sea current along the west coast of Sumatra Island and Malacca straits, respectively. 
region. We believe this information will be important not only in the field of botany but also for resource management of the different vegetation zones in West Sumatra.

\section{MATERIALS AND METHODS}

\section{Study site}

The study sites were located on the western slopes of the Barisan range, facing the Padang Plain in West Sumatra (Fig. 1). Observations were carried out on two mountains within the Barisan range: Gunung Gadut (1859 m, 00 54-57' S, $\left.100^{\circ} 30-33^{\prime} \mathrm{E}\right), 15-20 \mathrm{~km}$ east of Padang city, and Bukit Sibakaljawi (1309 m, 00 32-34'S, 100 21-23’E), $50 \mathrm{~km}$ north of Padang city. "Gunung" and "Bukit" both mean mountains in Indonesian.

A total of 10 plots were established in these 2 study sites (Table 1). Six plots were established on the main ridge of Gunung Gadut, from the foothill village of Koto Baru in Ulu Gadut to the summit, at approximately 200-m vertical intervals at 600, 850, 990, 1280, 1600 and $1780 \mathrm{~m}$ asl. The upper 2 plots were located on the shoulder of the mountain. These plots were named G600, G850, G990, G1280, G1600 and G1780, respectively. G600 and G1600 were established under the Sumatra Nature Study Project (Ogino et al., 1984), and G600 was later expanded from its original area of 1 ha to 6.55 ha (Nishimura et al., 2006). The remaining 5 plots had a nearly identical size of about 0.1 ha $(20 \times 50$ or $60 \mathrm{~m})$.

The remaining four plots were established at 200-m vertical intervals at $600,800,1000$, and $1200 \mathrm{~m}$ asl on the main ridge of Bukit Sibakaljawi, from the foothill village of Sipisang to the summit. The plots were named S600,
S800, S1000 and S1200, respectively, and ranged in area from 0.5 to 1.0 ha (Table 1 ).

The 10 plots seemed to be primary forest in terms of their physiognomy (Appendixes 1 and 2), although trees in the lower plots below $1000 \mathrm{~m}$ asl had been logged selectively by local residents. The logging impact on these stands was previously shown to be considerably less than that of mechanized logging (Nishimura et al., 2006).

\section{Climate of Padang region}

Data of rainfall and the direction of maximum wind recorded at Tabing meteorological station in Padang city since 1971 were used to explain the macroclimate of this region. The warm Indian Ocean current running along the west coast of Sumatra (Fig. 1) results in a large amount of water vapor, which is then carried by the outstandingly frequent winds blowing from southwest to west-southwest (Fig. 2a) to the slopes of the Barisan range. The Barisan range acts as a barrier interrupting this wind and an air bump consequently develops along the slope of the range. This air then becomes cloud with cooling of the water vapor. This mechanism likely explains the abundant cloudy days and heavy rain in Padang region.

According to the meteorological data of Tabing International Airport in Padang city (ca. $3 \mathrm{~m}$ asl; $00^{\circ}$ 53' $\mathrm{S}, 100^{\circ} 21^{\prime} \mathrm{E}$ ), the mean annual rainfall over $33 \mathrm{yrs}$ from 1971 to 2003 was $4,217 \mathrm{~mm}$ (Table 2). The minimum monthly rainfall was $270 \mathrm{~mm}$ without a clear dry season (Fig. 2b). The annual rainfall in Indarung town (ca. 200 $\mathrm{m}$ asl), at the foot of Gunung Gadut, reaches about 5,900 $\mathrm{mm}$ (Kohyama and Hotta, 1986). These findings suggest

Table 1. Outline of the study plot in Gunung Gadut and Bukit Sibakaljawi. Soil group was reffered to United States Department of Agriculture, Natural Resources Conservation Service (1999).

\begin{tabular}{llrrl}
\hline Mountain name & $\begin{array}{l}\text { Plot } \\
\text { name }\end{array}$ & $\begin{array}{c}\text { Altitude } \\
(\mathrm{m})\end{array}$ & $\begin{array}{c}\text { Area } \\
\left(\mathrm{m}^{2}\right)\end{array}$ & Soil group \\
\hline Gunung Gadut & G600 & $546-654$ & 65500 & Typic Dystropepts \\
& G850 & 850 & 1000 & Typic Troporthents \\
& G990 & 990 & 1000 & Typic Hapludults \\
& G1280 & 1280 & 1200 & Udipsamment \\
& G1600 & 1600 & 883 & Andic Humitropepts \\
& G1780 & 1780 & 1000 & Lithic Tropohemists \\
& S600 & 600 & 9810 & Typic Dystropepts \\
& S800 & 800 & 4574 & Oxic Dystropepts \\
& S1000 Sibakaljawic & 4560 & Andic/Typic Dystropepts \\
& S1200 & 1000 & 4605 & Typic Hapludands \\
\hline
\end{tabular}



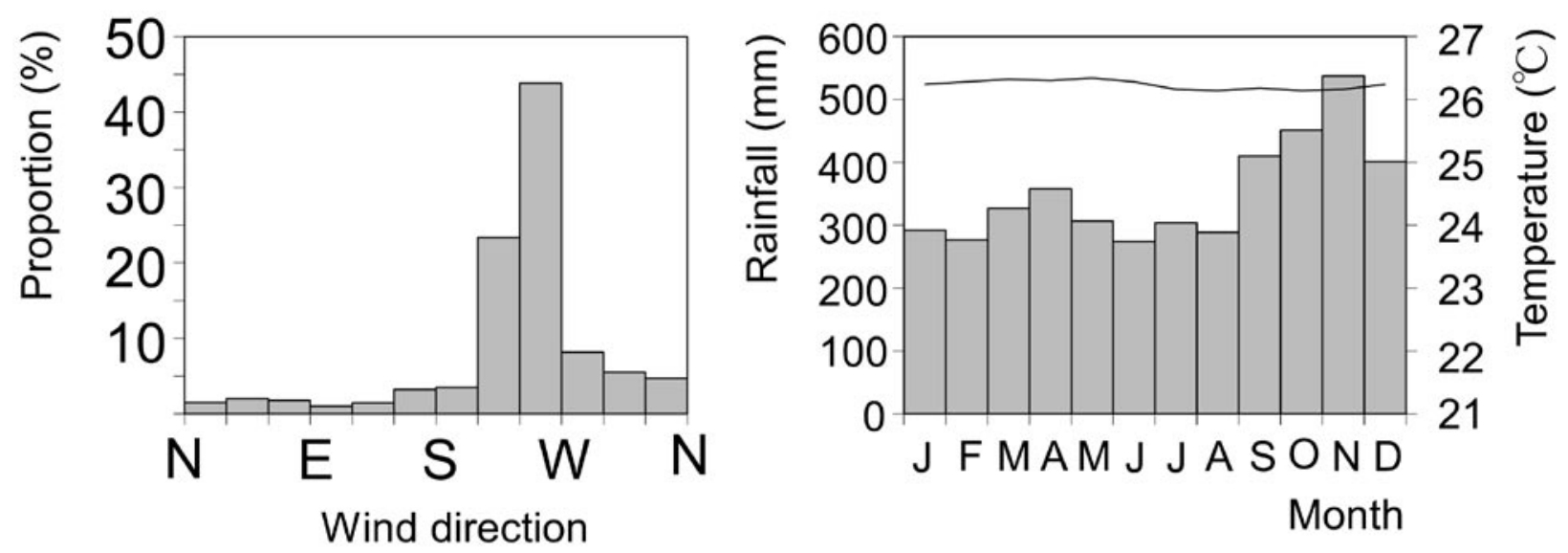

Fig. 2. a(Left): Frequency distribution of wind direction at Tabing International Airport from 1971-1998. b(Right): Average monthly rainfall (bar graph) and temperature (line graph) at Tabing International Airport, Padang city. The rainfall data was based on meteorological data recorded daily from 1971-2003. The temperature data was obtained from National Astronomical Observatory (1999) data from 1961-1990.

Table 2. Average air temperature $\left({ }^{\circ} \mathrm{C}\right)$ and annual rainfall $\left(\mathrm{mm}\right.$ year $\left.{ }^{-1}\right)$ of major region in West Malesia. Annual rainfall data of Padang was calculated from the data of Tabing International Airport. All the other data were reffered from National Astronomical Observatory (1999).

\begin{tabular}{llccc}
\hline Geological region & City & $\begin{array}{c}\text { Altitude } \\
(\mathrm{m})\end{array}$ & $\begin{array}{c}\text { Average } \\
\text { air temperature } \\
\left({ }^{\circ} \mathrm{C}\right)\end{array}$ & $\begin{array}{c}\text { Annual } \\
\text { rainfall } \\
\left(\mathrm{mm}^{-1} \text { year }\right.\end{array}$ \\
\hline Sumatra & Padang & 3 & 26.1 & 4217 \\
& Medang & 25 & 26.3 & 2186 \\
Malay Peninsular & Kota Bharu & 5 & 26.7 & 1982 \\
& Kuala Lumpur & 22 & 26.6 & 2569 \\
Borneo & Singapore & 32 & 26.7 & 2343 \\
& Sandakan & 13 & 26.8 & 3087 \\
& Pontianak & 3 & 26.2 & 3354 \\
\hline
\end{tabular}

that the annual rainfall in the study plots, which are at elevations higher than the above metrological stations, is possibly higher than these estimations.

\section{Tree census}

The stem diameter at breast height (dbh) and position of all trees with a $\mathrm{dbh} \geq 10 \mathrm{~cm}$ were measured in each plot. The basal area of the stand was calculated with all shoots, including sprouting shoots, and tree density was calculated based on the number of individuals. Forest profiles (cross-sections) were drawn for each plot. Trees were tentatively identified in the field according to their local names based on the bark and wood characteristics of the trunk then small branches with fresh leaves were collected and used for final identification at the
Herbarium Bogorience, Bogor. All specimens are housed in the Herbarium of Andalas University, with duplicates in Kagoshima University, Japan (Yoneda, 2004). Arecaceae, climbers and stranglers were excluded from this analysis. General structural features of the 10 plots are shown in Table 3.

Logged stumps resulting from local logging were found in G600, G850, G990, S600 and S800. All were initially identified based on their wood, bark and buttress characteristics, then wood samples were collected for species identification by anatomical analysis at the Forest and Forest Product Research Institute in Tsukuba, Japan. Stem diameter at the top of the stump and the position of the stump base were also recorded. The results of stump identification in G600 can be referred to in Nishimura $e t$ 
Table 3. Structural features of the 10 study plots determined using stems with a dbh of greater than $10 \mathrm{~cm}$.

The average height of the canopy layer, maximum tree height, stem density, maximum dbh, BA1 (total basal area of living trees) per hectare, BA2 (total basal area of living trees and logged stamps) per hectare and the percentage of stump BA per total BA2 in the study plots in Gunung Gadut \& Bukit Sibakaljawi.

\begin{tabular}{|c|c|c|c|c|c|c|c|c|}
\hline Mountain name & Plots & $\begin{array}{c}\text { Average } \\
\text { canopy } \\
\text { height } \\
(\mathrm{m})\end{array}$ & $\begin{array}{l}\text { Max. } \\
\text { Tree } \\
\text { height } \\
(\mathrm{m})\end{array}$ & $\begin{array}{c}\text { Stem } \\
\text { density } \\
\left(\mathrm{Nha}^{-1}\right)\end{array}$ & $\begin{array}{l}\text { Max } \\
\text { dbh } \\
(\mathrm{cm})\end{array}$ & $\underset{\left(\mathrm{m}^{2} \mathrm{ha}^{-1}\right)}{\mathrm{BA}}$ & $\begin{array}{c}\text { BA2 } \\
\text { (stumps } \\
\text { included) } \\
\left(\mathrm{m}^{2} \mathrm{ha}^{-1}\right) \\
\end{array}$ & $\begin{array}{c}\text { Percentage } \\
\text { of } \\
\text { stump BA } \\
(\%)\end{array}$ \\
\hline \multirow[t]{6}{*}{ Gunung Gadut } & G600 & $30-40$ & 58 & 522 & 142 & 30 & 32 & 4 \\
\hline & G850 & $25-30$ & 30 & 830 & 89 & 46 & 53 & 13 \\
\hline & G990 & $25-30$ & 36 & 720 & 87 & 49 & 56 & 11 \\
\hline & G1280 & $25-30$ & 31 & 1092 & 65 & 50 & 50 & - \\
\hline & G1600 & 20 & 20 & 1190 & 59 & 39 & 39 & - \\
\hline & G1780 & 20 & 18 & 1210 & 64 & 32 & 32 & - \\
\hline \multirow[t]{4}{*}{ Bukit Sibakaljawi } & $\mathrm{S} 600$ & $30-35$ & 47 & 750 & 118 & 47 & 50 & 7 \\
\hline & $\mathrm{S} 800$ & 30 & 34 & 828 & 77 & 48 & 54 & 11 \\
\hline & $\mathrm{S} 1000$ & $25-30$ & 36 & 669 & 89 & 33 & 33 & - \\
\hline & $\mathrm{S} 1200$ & $25-30$ & 26 & 678 & 77 & 32 & 32 & - \\
\hline
\end{tabular}

al. (2006).

\section{Similarity analysis of vegetation}

The 10 plots were classified using cluster analysis and similarity among the plots was determined using a quantitative similarity index, Percent Similarity (PS) (Whittaker 1952). $P S=$ the sum of the smaller relative basal area of common species between two samples:

$P S=\sum_{i=l}^{S} \min \left(a_{i j}, a_{i k}\right)$

where $a_{i j}$ and $a_{i k}$ denote the relative basal area of the $i$ th species in the $j$ th and $k$ th plots, respectively, and $s$ denotes the total number of species. An agglomerative method was employed to construct a dendrogram. The $P S$ between plot clusters was re-calculated at each step of dendrogram construction using species dominance data averaged within each cluster.

Two-way indicator species analysis (TWINSPAN) was employed to assess the floristic similarity among plots at the species level and to determine the indicator species of each plot. A total of 682 species identified to the species level in the 10 plots were applied to this analysis. This program first constructs a classification of the sample plots and is then used for species classification according to ecological preferences (Hill, 1979).

\section{Climate data}

The air temperature in the 10 plots at $1.3 \mathrm{~m}$ from ground level was measured for 327 days at 30-minute intervals from November 1997 to October 1998 in G600, G850, S600, S800, S1000, and S1200, and from January 1998 to November 1998 in G990, G1280, G1600 and G1780 using thermo recorders (Ondotori; T\&D Corporation). Based on these data, we assessed the climatic conditions of the altitudinal zonation using Kira's Warmth Index (WI), a kind of cumulative temperature index (Kira 1976):

$W I=\sum_{l}^{n}(T-5)$

where $n=$ the number of months with a mean monthly air temperature $(T)$ exceeding $5{ }^{\circ} \mathrm{C}$.

\section{RESULTS}

\section{Altitudinal gradient of air temperature}

The mean, maximum, minimum, mean daily maximum and mean daily minimum air temperatures in the 10 plots are shown in Table 4. The mean air temperature represents the mean values of all temperatures recorded over one year from November 1997. All five kinds of temperature decreased linearly with increasing altitude. The following two regressions were observed for the correlation between altitude $(X: \mathrm{m})$ and the mean annual air temperature $\left(Y:{ }^{\circ} \mathrm{C}\right)$ :

$$
Y=-0.0056 X+26.07\left(\mathrm{R}^{2}=0.99\right)
$$

in Gunung Gadut and

$$
Y=-0.0058 X+26.00\left(\mathrm{R}^{2}=0.99\right)
$$


Table 4. Mean daily temperature, maximum temperature, minimum temperature, mean daily maximum temperature, mean daily minimum temperature $\left({ }^{\circ} \mathrm{C}\right)$ were collected by thermo recorders (Ondotori). WI value of ten plots was calculated based on Kira (1976).

\begin{tabular}{|c|c|c|c|c|c|c|c|}
\hline Mountain name & Plot & $\begin{array}{c}\text { t-mean } \\
\left({ }^{\circ} \mathrm{C}\right)\end{array}$ & $\begin{array}{c}\mathrm{t}-\max \\
\left({ }^{\circ} \mathrm{C}\right)\end{array}$ & $\begin{array}{c}\mathrm{t}-\min \\
\left({ }^{\circ} \mathrm{C}\right)\end{array}$ & $\begin{array}{c}\text { t-mean } \\
(\text { daily max }) \\
\left({ }^{\circ} \mathrm{C}\right)\end{array}$ & $\begin{array}{c}\text { t-mean } \\
\text { (daily min) } \\
\left({ }^{\circ} \mathrm{C}\right)\end{array}$ & $\begin{array}{c}\mathrm{WI} \\
\left({ }^{\circ} \mathrm{C} \cdot \mathrm{mo}\right)\end{array}$ \\
\hline \multirow[t]{5}{*}{ Gunung Gadut } & G600 & 22.5 & 28.5 & 17.4 & 24.6 & 21.0 & 209.6 \\
\hline & G850 & 21.5 & 27.4 & 16.3 & 23.6 & 20.1 & 198.2 \\
\hline & G990 & 20.5 & 26.5 & 16.1 & 22.6 & 19.2 & 185.1 \\
\hline & G1280 & 19.0 & 26.6 & 15.1 & 21.6 & 17.7 & 169.0 \\
\hline & G1600 & 17.1 & 24.5 & 13.2 & 19.6 & 15.6 & 143.5 \\
\hline \multirow[t]{4}{*}{ Bukit Sibakaljawi } & $\mathrm{S} 600$ & 22.3 & 28.6 & 17.5 & 24.6 & 20.6 & 207.4 \\
\hline & S800 & 21.5 & 27.5 & 17.0 & 23.7 & 20.1 & 198.2 \\
\hline & S1000 & 20.0 & 25.6 & 15.9 & 21.9 & 18.7 & 179.7 \\
\hline & S1200 & 19.3 & 26.7 & 14.4 & 21.1 & 18.0 & 171.3 \\
\hline
\end{tabular}

Table 5. Lapse rates of mean, maximum and minimum air temperature $\left({ }^{\circ} \mathrm{C}\right)$ and presumed altitude $(\mathrm{m})$ of $22.5^{\circ} \mathrm{C}$ (annual mean temperature at G600) in 9 region.

\begin{tabular}{|c|c|c|c|c|c|c|}
\hline \multirow{2}{*}{$\begin{array}{l}\text { Geological } \\
\text { region }\end{array}$} & \multirow{2}{*}{ Study site } & \multicolumn{3}{|c|}{ laps rate $\left({ }^{\circ} \mathrm{C}\right.$ per $\left.100 \mathrm{~m}\right)$} & \multirow{2}{*}{$\begin{array}{l}\text { alt of } 22.5^{\circ} \mathrm{C} \\
\text { (m) }\end{array}$} & \multirow{2}{*}{ Refference } \\
\hline & & mean & maximum & minimum & & \\
\hline \multirow[t]{2}{*}{ Sumatra } & Gunung Gadut & 0.56 & 0.53 & 0.54 & $638^{*}$ & This study \\
\hline & Bukit Sibakaljawi & 0.58 & 0.61 & 0.46 & $603^{*}$ & This study \\
\hline \multirow[t]{3}{*}{ Malay Peninsular } & Cameron Highland & 0.55 & - & - & $745^{* *}$ & (Burgess 1969) \\
\hline & Island hill of Pinang Island & 0.61 & - & - & $672^{* *}$ & (Burgess 1969) \\
\hline & Gombak \& Genting Highland & - & 0.44 & 0.43 & - & (Nakashizuka et al. 1992) \\
\hline \multirow[t]{3}{*}{ Borneo } & Gunung Mulu & 0.50 & - & - & $860^{* * *}$ & (Proctor et al. 1983) \\
\hline & Gunung Silam & 0.48 & 0.53 & 0.46 & $896^{* * *}$ & (Proctor et al. 1988) \\
\hline & Mt. Kinabalu & 0.55 & 0.62 & 0.49 & $900^{* * * *}$ & (Kitayama 1992) \\
\hline Malesia General & & 0.67 & - & - & - & (Whitmore 1984) \\
\hline
\end{tabular}

*Using regressions in text. " Using $0 \mathrm{~m}$ asl data of Kuala Lumpur (National Astronomical Observatory 1999). ${ }^{* * *}$ Using $0 \mathrm{~m}$ asl data of Sandakan (National Astronomical Observatory 1999). ${ }^{* * *}$ Using following regressions: $\mathrm{Y}=-0.0055 \mathrm{X}+27.45$ (Kitayama 1992)

in Bukit Sibakaljawi. The mean annual temperature in Padang city was also used for the calculations of lowland areas. These regressions suggest that lapse rates of temperature are $0.56 \pm 0.01{ }^{\circ} \mathrm{C} \cdot 100 \mathrm{~m}^{-1}$ in Gunung Gadut and $0.58 \pm 0.03{ }^{\circ} \mathrm{C} \cdot 100 \mathrm{~m}^{-1}$ in Bukit Sibakaljawi, which are lower than the often used rate of $0.67{ }^{\circ} \mathrm{C} \cdot 100 \mathrm{~m}^{-1}$ (Whitmore, 1984). However, they are also either the same or slightly higher than those of other specific regions in West Malesia (Table 5). The estimated altitudes with a temperature of $22.5{ }^{\circ} \mathrm{C}$, the mean annual temperature in $\mathrm{G} 600$, in other West Malesia regions is also shown in Table 5.

The WI values of the 10 plots ranged from 132 to $210{ }^{\circ} \mathrm{C} \cdot$ month, dividing the plots into two climatic zones, a subtropical zone $(240>\mathrm{WI} \geq 180)$ and montane zone corresponding to a warm temperate climate $(180>\mathrm{WI}$ $\geq 85$ ). The borderline was estimated as around $1000 \mathrm{~m}$ asl in Gunung Gadut and Bukit Sibakaljawi (Fig. 3). The WI of both regions were clearly regressed by altitude according to the following equation:

$$
\mathrm{WI}=-0.0676 X+252.57\left(\mathrm{R}^{2}=0.99\right)
$$

in Gunung Gadut and

$$
\mathrm{WI}=-0.0635 X+246.31\left(\mathrm{R}^{2}=0.98\right)
$$

in Bukit Sibakaljawi.

\section{Classification of vegetation}

The percentage similarities $(P S)$ between all pairs of plots are shown in Table 6 . Twelve of the total 45 pairs showed 


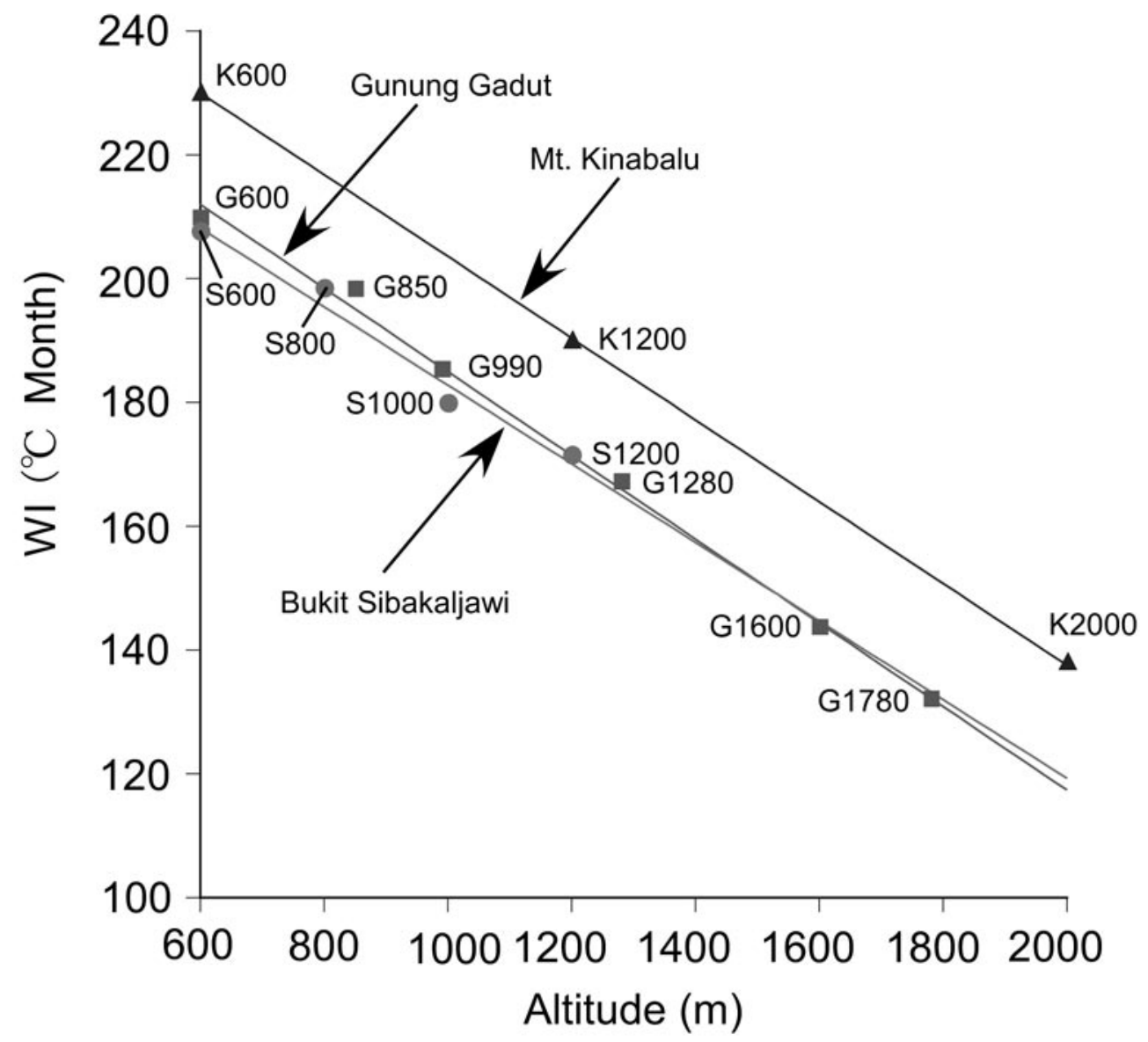

Fig. 3. Relationship between the warmth index and altitude in Gunung Gadut ( $\square$ ), Bukit Sibakaljawi (O) and Mt. Kinabalu $(\Delta)$. The warmth index values were based on direct measurements obtained using a data logger. The Mt. Kinabalu data is after Kitayama (1992).

Table 6. Percentage similarities among plots. The similarity between two plots was calculated based on the proportion of species common to both plots. Basal area data were employed to determine the dominance of each species in each plot. Underlined values show a percentage similarity of more than $10 \%$.

\begin{tabular}{|c|c|c|c|c|c|c|c|c|c|}
\hline & G-850 & G-990 & G-1280 & G-1600 & G-1780 & S-600 & S-800 & S-1000 & S-1200 \\
\hline \multirow[t]{9}{*}{ G-600 } & 9.7 & 6.5 & 1.2 & 0.4 & 0.2 & $\underline{20.5}$ & $\underline{15.3}$ & 9.0 & 6.0 \\
\hline & G-850 & $\underline{12.8}$ & 3.5 & 0.0 & 0.0 & $\underline{12.2}$ & $\underline{18.7}$ & 9.6 & 6.0 \\
\hline & & G-990 & 5.8 & 0.0 & 2.4 & 3.7 & 5.3 & $\underline{10.3}$ & 2.4 \\
\hline & & & G-1280 & 2.2 & 2.6 & 2.9 & 1.7 & $\underline{13.1}$ & 4.1 \\
\hline & & & & G-1600 & $\underline{17.6}$ & 0.6 & 1.9 & 0.5 & 1.3 \\
\hline & & & & & G-1780 & 0.2 & 0.0 & 0.0 & 0.2 \\
\hline & & & & & & $\mathrm{S}-600$ & $\underline{27.5}$ & $\underline{12.7}$ & 7.3 \\
\hline & & & & & & & S-800 & $\underline{18.1}$ & 7.6 \\
\hline & & & & & & & & S-1000 & $\underline{15.3}$ \\
\hline
\end{tabular}




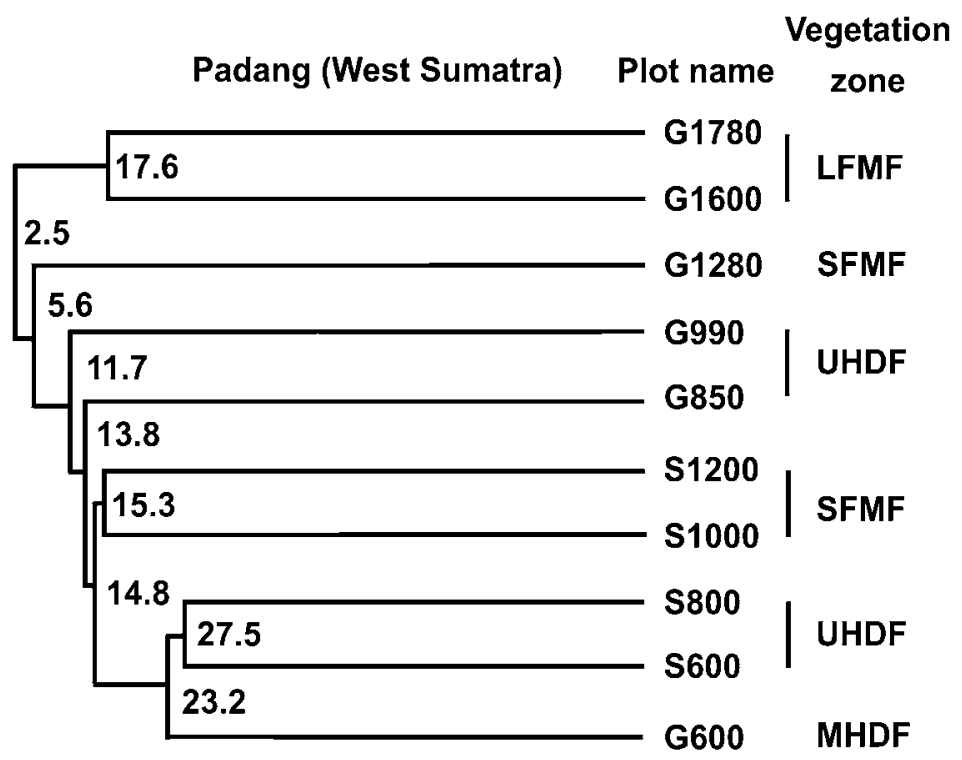

Mt. Kinabalu (Borneo)
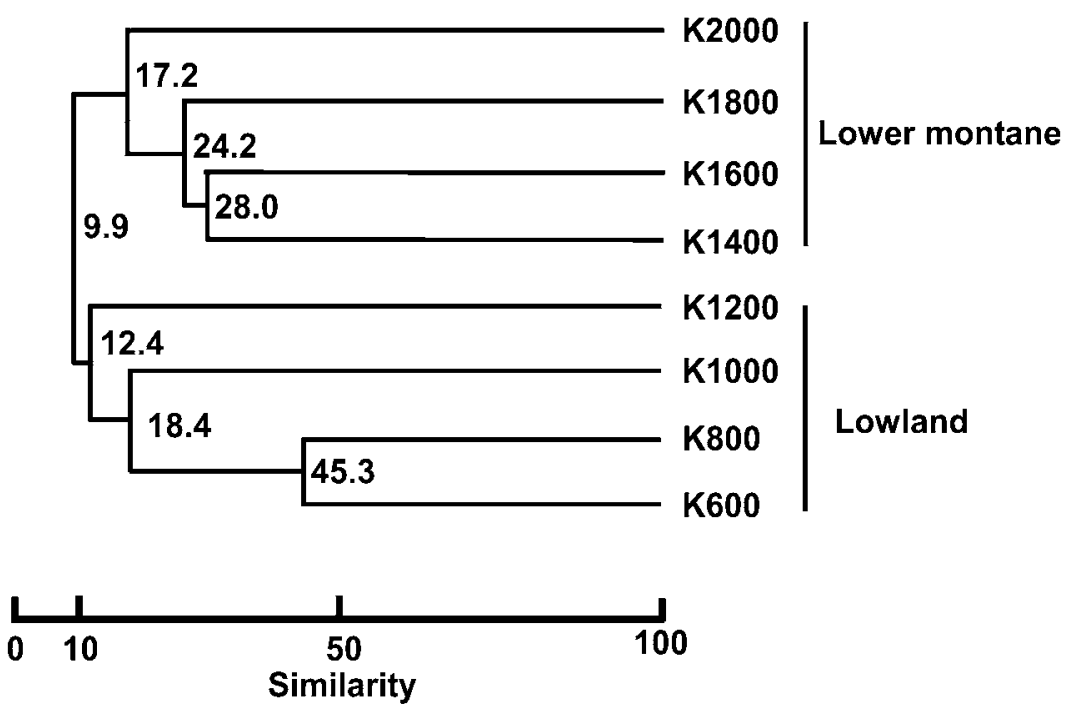

(\%)

Fig. 4. Dendrograms showing the altitudinal series in Padang and Mt. Kinabalu. The Mt. Kinabalu data is after Kitayama (1992). Only 8 of 14 plots on Mt. Kinabalu from 600 to $3400 \mathrm{~m}$ asl were employed in this analysis. Details of the vegetation zones are described in the main text.

high similarity greater than $10 \%$. The Gunung Gadut plots below $1300 \mathrm{~m}$ tended to show high similarity with plots at corresponding altitudes in Bukit Sibakaljawi; for example, G-600 and S-600, and G-850 and S-800. In each region, adjoining pairs of plots also tended to show high similarity; for example, G-1600 and G-1780, S-600 and S-800. This tendency was clearer in Bukit Sibakaljawi. These findings suggest that species composition changes gradually with altitude in both regions and that the two mountains have similar altitudinal gradients.

A dendrogram of the 10 plots was constructed based on the $P S$ findings. Three clusters were recognizable at a $10 \%$ threshold (Fig.4). They consisted of G1600-G1780, G1280, and all others, and were arranged along the altitudinal gradient. The third cluster consisted of 4 groups, G990, G850, G600-S600-S800, and S1000-S1200, at a $15 \%$ threshold. The S1000-S1200 cluster showed higher similarity with the lower altitude cluster of G600-S600-S800 than the plots at corresponding altitudes in Gunung Gadut. S600 also formed a cluster with S800 at a $25 \%$ threshold, but without G600, the plot at a corresponding altitude in Gunung Gadut. These two arrangements showed more regional than altitudinal grouping.

A total of 682 species were used to classify the 10 plots using TWINSPAN (Table 7). In the table, indicator species are shown with their relative basal area (\%) classes: 5, 20-100\%; 4, 10-19\%; 3, 5-9\%; 2, $1-4 \% ; 1,0-1 \%$. Up to the fourth division level, the 10 sample plots could be divided into five clusters. This classification correlated well with the results of cluster analysis.

The first division separated the higher two plots in Gunung Gadut from those at a lower altitude, and the second division separated G1280 from those at a lower altitude. The first group was characterized by moderate to high dominance (ranked greater than class 2) of certain indicator species found in this group only; namely, Elaeocarpus punctantus, Leptospermum flavescens, Lithocarpus cf. lampadaria and Anneslea fragrans. The second group, G1280, was distinguished by 6 indicator species with moderate dominance (class 2-3); however, this group included a few other species common to the former group and remaining plots. The third division 
Table 7. Classification of plots and indicator species of each cluster obtained by TWINSPAN. Sample clusters up to the fourth division level are indicated by a binary system $(0 \& 1)$ at the bottom of this table. Low dominant species, less than $1 \%$ in a single plot, were omitted. Values in the table are based on relative basal area classes: $5,20-100 \% ; 4,10-19 \% ; 3,5-9 \% ; 2,1-4 \% ; 1,0-1 \%$.

\begin{tabular}{|c|c|c|c|c|c|c|c|c|c|c|c|c|}
\hline & & & \multicolumn{2}{|c|}{ (5) } & \multicolumn{3}{|c|}{ (4) } & \multicolumn{2}{|c|}{ (3) } & \multirow{2}{*}{$\frac{(2)}{G}$} & \multicolumn{2}{|c|}{ (1) } \\
\hline & & & $\mathrm{S}$ & $\mathrm{S}$ & $\mathrm{S}$ & $\mathrm{S}$ & G & $\mathrm{G}$ & $\mathrm{G}$ & & $\bar{G}$ & $\bar{G}$ \\
\hline & & & 1 & 1 & 8 & 6 & 6 & 8 & 9 & 1 & 1 & 1 \\
\hline & & plot & 2 & 0 & 0 & 0 & 0 & 5 & 9 & 2 & 6 & 7 \\
\hline & & & 0 & 0 & 0 & 0 & 0 & 0 & 0 & 8 & 0 & 8 \\
\hline Species name & Family & & 0 & 0 & & & & & & 0 & 0 & 0 \\
\hline \multicolumn{13}{|l|}{ (1) indicator species } \\
\hline Elaeocarpus punctantus & Elaeocarpaceae & & - & - & - & - & - & - & - & - & - & 3 \\
\hline Leptospermum flavescens & Myrtaceae & & - & - & - & - & - & - & - & - & - & 4 \\
\hline Lithocarpus cf. lampadaria & Fagaceae & & - & - & - & - & - & - & - & - & 4 & 5 \\
\hline Anneslea fragrans & Theaceae & & - & - & - & - & - & - & - & - & 2 & 2 \\
\hline Litsea diversifolia & Lauraceae & & - & - & 1 & 1 & 1 & - & - & - & 2 & - \\
\hline Ellipanthus tomentosus & Connaraceae & & 1 & - & - & - & 1 & - & - & - & 2 & - \\
\hline \multicolumn{13}{|l|}{ (1),(2) indicator species } \\
\hline Podocarpus neriifolius & Podocarpaceae & & 1 & - & - & - & - & - & - & 2 & 2 & - \\
\hline Ficus pubinervius Bl. & Moraceae & & - & - & - & - & - & - & - & 2 & - & 2 \\
\hline \multicolumn{13}{|l|}{ (2) indicator species } \\
\hline Garcinia celebica & Guttiferae & & - & - & - & - & 1 & - & - & 3 & - & - \\
\hline Eugenia clavimyrthus & Myrtaceae & & - & 1 & - & - & 1 & - & - & 2 & - & - \\
\hline Palaquium rostratum & Sapotaceae & & - & - & - & - & 1 & - & - & 2 & - & - \\
\hline Chionanthus laxiflorus & Oleaceae & & - & - & - & - & - & 1 & - & 3 & - & - \\
\hline Garcinia rostrata & Guttiferae & & 1 & 1 & - & - & - & - & - & 3 & - & - \\
\hline Ternstroemia aneura & Theaceae & & - & - & - & - & - & - & - & 3 & - & - \\
\hline \multicolumn{13}{|c|}{$(2),(3),(5)$ indicator species } \\
\hline Lithocarpus bennettii & Fagaceae & & 1 & 4 & 1 & 1 & - & - & 2 & 4 & - & - \\
\hline Lithocarpus sp. 2 & Fagaceae & & - & 3 & 1 & - & - & 2 & 2 & 1 & - & - \\
\hline Eugenia cuprea & Myrtaceae & & 3 & - & - & - & 1 & 1 & - & 1 & - & - \\
\hline Eugenia cymosa & Myrtaceae & & 2 & 1 & 1 & 1 & 1 & 1 & 1 & 2 & - & - \\
\hline (3) indicator species & & & & & & & & & & & & \\
\hline Eugenia magnoliaefolia & Myrtaceae & & - & - & - & - & - & 2 & 1 & - & - & - \\
\hline Calophyllum soulatri & Guttiferae & & - & - & - & 1 & 1 & 1 & 2 & - & - & - \\
\hline Quercus oidocarpa & Fagaceae & & - & - & - & - & 1 & 4 & 2 & - & - & - \\
\hline Shorea ovata & Diptercarpaceae & & - & - & - & - & - & 3 & 3 & - & - & - \\
\hline Eugenia filiformis & Myrtaceae & & - & 1 & 1 & - & - & 3 & - & - & - & - \\
\hline Santiria rubiginosa & Burseraceae & & - & - & - & - & 1 & 4 & - & - & - & - \\
\hline Eugenia zippeliana & Myrtaceae & & - & - & - & 1 & 1 & - & 2 & - & - & - \\
\hline Aglaia odoratissima & Meliaceae & & 1 & - & - & - & 1 & - & 4 & - & - & - \\
\hline Canarium denticulatum & Burseraceae & & - & 1 & - & - & 1 & - & 4 & - & - & - \\
\hline (3),(4) indicator specie & & & & & & & & & & & & \\
\hline Shorea platyclados & Diptercarpaceae & & - & 1 & 4 & 3 & - & 4 & 2 & - & - & - \\
\hline Lithocarpus meijeri & Fagaceae & & - & - & - & - & 2 & 2 & 4 & - & - & - \\
\hline (4) indicator species & & & & & & & & & & & & \\
\hline Swintonia schwenkii & Anacardiaceae & & - & - & - & 3 & 2 & - & - & - & - & - \\
\hline Shorea retinoides & Diptercarpaceae & & - & - & - & 2 & 1 & - & - & - & - & - \\
\hline Vatica perakensis cf. & Diptercarpaceae & & - & - & 2 & 1 & 1 & - & - & - & - & - \\
\hline Glochidion rubrum & Euphorbiaceae & & - & - & 2 & 1 & 1 & - & - & - & - & - \\
\hline Alseodaphne falcata & Lauraceae & & - & - & 2 & 1 & - & - & - & - & - & - \\
\hline Eugenia besukiensis & Myrtaceae & & - & - & 3 & 2 & - & - & - & - & - & - \\
\hline Quercus argentata & Fagaceae & & - & 2 & 3 & 2 & 1 & - & - & - & - & - \\
\hline (4),(5) indicator specie & & & & & & & & & & & & \\
\hline Eugenia inophylla & Myrtaceae & & 1 & 2 & 1 & - & 1 & - & - & - & - & - \\
\hline Litsea firma & Lauraceae & & 1 & 2 & - & 1 & 1 & - & - & - & - & - \\
\hline Pternandra coerulescens & Melastomataceae & & 2 & 1 & 1 & 1 & 1 & - & - & - & - & - \\
\hline (5) indicator species & & & & & & & & & & & & \\
\hline Bhesa paniculata & Celastoracaeae & & 2 & - & 1 & 1 & 1 & 2 & - & - & - & - \\
\hline Schima noronhae & Theaceae & & 3 & 1 & 1 & 1 & - & - & 1 & - & - & - \\
\hline Heliciopsis incisa & Proteaceae & & 2 & - & - & - & 1 & - & - & - & - & - \\
\hline Eugenia attenuata & Myrtaceae & & 2 & 3 & 1 & 1 & - & - & - & - & - & - \\
\hline Alseodaphne bancana & Lauraceae & & 3 & 1 & - & 1 & - & - & - & - & - & - \\
\hline Lithocarpus daphnoideus & Fagaceae & & 4 & - & - & 1 & - & - & - & - & - & - \\
\hline Calophyllum venulosum & Guttiferae & & 2 & 1 & - & - & - & - & - & - & - & - \\
\hline Rapanea hasseltii & Myrsinaceae & & 2 & 1 & - & - & - & - & - & - & - & - \\
\hline Atuna excelsa & Rosaceae & & 1 & 3 & - & - & - & - & - & - & - & - \\
\hline & Level 1 & & 0 & 0 & 0 & 0 & 0 & 0 & 0 & 0 & 1 & 1 \\
\hline & Level 2 & & 0 & 0 & 0 & 0 & 0 & 0 & 0 & 1 & & \\
\hline & Level 3 & & 0 & 0 & 0 & 0 & 0 & 1 & 1 & & & \\
\hline & Level 4 & & 0 & 0 & 1 & 1 & 1 & & & & & \\
\hline
\end{tabular}




\begin{tabular}{c|l|l|l|l|l|l|}
$\begin{array}{l}\text { Elevation } \\
(\mathrm{m}) \\
2000\end{array}$ & \multicolumn{2}{|c|}{$\begin{array}{l}\text { Proposed altitudinal zonation } \\
\text { Padang region, West Sumatra }\end{array}$} & \multicolumn{2}{l}{$\begin{array}{l}\text { Sumatra (mainly east Barisan) } \\
\text { (Laumonier 1997)* }\end{array}$} \\
(Wyatt-Smith 1964)
\end{tabular}

Fig. 5. Proposed altitudinal zonation of Padang region, West Sumatra, and those of East Sumatra (after Laumonier 1997), Malay Peninsular (after Wyatt-Smith 1964) and Borneo (Mt. Kinabalu; after Kitayama 1992). The upper altitudinal limit of Dipterocarpaceae in each region is shown by an asterisk. The bold line represents the border between the lowland and montane zone.

a few other species common to the former group and remaining plots. The third divisionseparated G850 and G990 from the 4 plots in Bukit Sibakaljawi and G600. Nine species including Quercus oidocarpa and Shorea ovata were mainly distributed in this group. The fourth division separated S1000 and S1200 from G600, S600, and S800. Nine species were shown to be indicator species of $\mathrm{S} 1000$ and S1200. These two plots formed a group with three low altitude plots, namely, G600, S600, and S800, each with four low dominance (class 1-2) indicator species, and had the same four indicator species of Fagaceae and Myrtaceae as the two corresponding altitude groups of G850-G990 and G1280. In terms of the distribution of Shorea species, only lowland to hill dipterocarp species such as $S$. maxiwelliana, $S$. atrinervosa, $S$. ovalis and $S$. lepidota were found in G600. In S600, on the other hand, not only lowland to hill species such as $S$. hopeifolia, but also hill to upper hill specific species such as $S$. retinoides and S. platyclados emerged as top layer trees. In S800, only $S$. platyclados was observed.

\section{DISCUSSION}

\section{Altitudinal zonation of vegetation}

TWINSPAN divided the vegetation in Padang region into 5 groups up to the fourth cut-off level, and cluster analysis divided the vegetation into 7 groups at a $15 \%$ threshold. Our aim was therefore to define the altitudinal vegetation zones in this region based on this grouping information, physiognomical information, and information on family-level dominance in each plot, referring to former studies conducted in East Sumatra (Laumonier, 1997), Malay Peninsular (Wyatt-Smith, 1963; based on Symington, 1943, reprinted in 1974), and Mt. Kinabalu,
Borneo (Kitayama 1992) (Fig. 5). In addition to the classic altitudinal zonation study of Symington (1974), the distribution of dipterocarps was also examined to define the zonation.

The G1600-G1780 cluster was similar to "Montane oak forest" in Malay Peninsular. The dominant families ( $\geq 10 \%$ dominance at the family level, Table 8 ) and forest physiognomy (Table 3, Appendix 1) of this cluster also corresponded well not only with Malay Peninsular but also "Montane forest" in East Sumatra and the "Lower montane zone" in Mt. Kinabalu; that is, with a remarkable dominance of Fagaceae and Myrtaceae. Moreover, in this cluster, epiphytes and moss increased in correlation with the high atmospheric humidity as a result of stagnation of clouds at this level. We therefore named this cluster "Lower montane Fago-myrtaceous forest" (LFMF).

As in LFMF, G1280 and S1200 were both codominated by representative montane families such as Fagaceae and Myrtaceae, and characterized by the absence of Dipterocarpaceae. However, the family composition and physiognomy were quite different from LFMF and agreed well with the upper zone (1200-1400 m) of "Sub-montane forest (800-1400 m)" sense Laumonier, being characterized by the absence of Dipterocarpaceae and high dominance of Guttiferae, Myrtaceae and Fagaceae, the absence of distinct emergents, a top layer $25-30 \mathrm{~m}$ in height and stems partly covered by moss. We named these two plots "Sub-montane Fago-myrtaceous forest" (SFMF). "Sub" represents the transition zone between the lowland and montane zones.

S1000 had a similar physiognomy and floristic characteristics as S1200. That is, it showed outstanding dominance of Fagaceae and Myrtaceae, and very low dominance of Dipterocarpaceae (0.4\%) suggestive of 
Table 8. Family rankings in terms of basal area (BA) and stem number for all trees $10 \mathrm{~cm}$ or greater in 6plots of Gunung Gadut and 4 plots of Bukit Sibakaljawi. The data for east of the barisan range is after Lamonier (1997). For 600, 850 and 990m in Gunung Gadut and 600 and 800m in Bukit Sibakaljawi, the proportion of dominance and abundance including logged tree are also shown in the blanket.

\begin{tabular}{|c|c|c|c|c|c|c|c|c|c|c|c|c|c|c|}
\hline \multirow[b]{3}{*}{ Plot name } & \multicolumn{5}{|c|}{ Gunung Gadut } & \multicolumn{5}{|c|}{ Bukit Sibakaljawi } & \multicolumn{4}{|c|}{ East of the Barisan } \\
\hline & \multirow[b]{2}{*}{ Rank } & \multicolumn{2}{|c|}{ Basal area } & \multicolumn{2}{|c|}{ Number of stems } & \multirow[b]{2}{*}{ Plot name } & \multicolumn{2}{|c|}{ Basal area } & \multicolumn{2}{|c|}{ Number of stems } & Basal & area & Number & tems \\
\hline & & Family & $\%$ & Family & $\%$ & & Family & $\%$ & Family & $\%$ & Family & $\%$ & Family & $\%$ \\
\hline G1780 & 1 & Faga & $\overline{27.5}$ & Faga & 20.8 & & & & & & & & & \\
\hline & 2 & Myrt & 22.8 & Elae & 16.7 & & & & & & & & & \\
\hline & 3 & Thea & 9.5 & Thea & 14.2 & & & & & & & & & \\
\hline & 4 & Elae & 9.0 & Myrt & 10.0 & & & & & & & & & \\
\hline & 5 & Rosa & 7.9 & Ruta & 8.3 & & & & & & & & & \\
\hline & 6 & Ruta & 7.4 & Rosa & 5.0 & & & & & & & & & \\
\hline & 7 & Mora & 2.1 & Laur & 4.2 & & & & & & & & & \\
\hline & 8 & Wint & 1.8 & Eric & 1.7 & & & & & & & & & \\
\hline & 9 & Laur & 1.7 & Mora & 1.7 & & & & & & & & & \\
\hline & 10 & Rubi & 1.6 & Rhiz & 1.7 & & & & & & & & & \\
\hline G1600 & 1 & Faga & $\overline{14.9}$ & 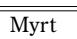 & 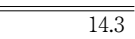 & & & & & & & & & \\
\hline & 2 & Myrt & 10.5 & Faga & 11.8 & & & & & & & & & \\
\hline & 3 & Laur & 7.7 & Thea & 7.6 & & & & & & & & & \\
\hline & 4 & Hama & 6.3 & Laur & 6.7 & & & & & & & & & \\
\hline & 5 & Gutt & 6.1 & Elae & 5.9 & & & & & & & & & \\
\hline & 6 & Thea & 4.8 & Olea & 5.9 & & & & & & Laumor & ier (199 & & \\
\hline & 7 & Burs & 3.9 & Euph & 5.0 & & & & & & Betweer & $900-14$ & $0 \mathrm{~m}$ & \\
\hline & 8 & Euph & 2.9 & Corn & 4.2 & & & & & & Location & unknowı & & \\
\hline & 9 & Olea & 2.7 & Cuno & 2.5 & & & & & & Only the & ranking & given. & \\
\hline & 10 & Elae & 2.2 & Gutt & 2.5 & & & & & & (9 most & epresent & d family) & \\
\hline G1280 & 1 & 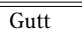 & 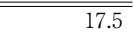 & Myrt & $\overline{17.6}$ & S1200 & Myrt & 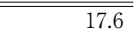 & Laur & 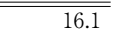 & Faga & - & Faga & - \\
\hline & 2 & Myrt & 12.4 & Thea & 13.7 & & Faga & 13.2 & Myrt & 11.3 & Myrt & - & Mora & - \\
\hline & 3 & Faga & 12.0 & Gutt & 13.0 & & Laur & 11.5 & Faga & 7.1 & Mora & - & Myrt & - \\
\hline & 4 & Rubi & 7.6 & Sapo & 6.9 & & Thea & 9.6 & Mora & 6.1 & Gutt & - & Gutt & - \\
\hline & 5 & Thea & 6.8 & Faga & 6.1 & & Gutt & 5.0 & Thea & 5.5 & Euph & - & Euph & - \\
\hline & 6 & Olea & 6.0 & Myrs & 6.1 & & Mora & 4.9 & Elae & 5.1 & Sapo & - & Sapo & - \\
\hline & 7 & Sapo & 5.4 & Olea & 5.3 & & Myrs & 4.9 & Myrs & 4.2 & Rosa & - & Rubi & - \\
\hline & 8 & Eric & 4.4 & Eric & 4.6 & & Cela & 3.7 & Euph & 3.9 & Sapo & - & Laur & - \\
\hline & 9 & Mela & 3.7 & Euph & 4.6 & & Elae & 3.2 & Gutt & 3.9 & Anac & - & Corn & - \\
\hline & 10 & Myrs & 3.1 & Myri & 3.8 & & Prot & 3.1 & Rubi & 3.5 & & & & \\
\hline G990 & 1 & $\overline{\mathrm{Myrt}}$ & 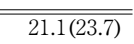 & $\overline{\text { Myrt }}$ & $\overline{\overline{22.2(22.9)}}$ & S1000 & Faga & $\overline{20.9}$ & Myrt & $\overline{\overline{18.2}}$ & & & & \\
\hline & 2 & Faga & 19.1(21.5) & Laur & $13.9(14.3)$ & & Myrt & 20.0 & Faga & 10.3 & & & & \\
\hline & 3 & Burs & 12.7(14.2) & Faga & $12.5(12.9)$ & & Rosa & 9.4 & Rosa & 7.6 & & & & \\
\hline & 4 & Meli & $12.5(14.0)$ & Dipt & $9.7(7.1)$ & & Laur & 8.3 & Laur & 7.3 & & & & \\
\hline & 5 & Dipt & $12.0(1.2)$ & Euph & $8.3(8.6)$ & & Elae & 3.8 & Mela & 6.0 & & & & \\
\hline & 6 & Laur & 8.3(9.4) & Meli & $5.6(5.7)$ & & Rhiz & 3.7 & Sapo & 5.0 & & & & \\
\hline & 7 & Gutt & $4.8(5.4)$ & Burs & $4.2(4.3)$ & & Sapi & 3.5 & Sapi & 4.0 & & & & \\
\hline & 8 & Euph & $3.6(4.0)$ & Gutt & $2.8(2.9)$ & & Anac & 2.8 & Myri & 3.6 & Laumor & ier $(199$ & & \\
\hline & 9 & Styr & $1.6(1.8)$ & Myri & $2.8(2.9)$ & & Icac & 2.5 & Rhiz & 3.3 & Bkt. Len & payang, a & t. $800 \mathrm{~m}$ & \\
\hline & 10 & Sapi & $0.7(0.8)$ & Elae & 1.4(1.4) & & Myri & 2.2 & Rubi & 3.3 & Merang & , Jambi & & \\
\hline G850 & 1 & Faga & $\overline{22.6(25.8)}$ & 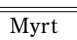 & $\bar{~} \overline{26.3(26.5)}$ & S800 & 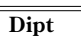 & $\overline{\overline{16.2(5.5)}}$ & Euph & 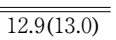 & Faga & $\overline{13.5}$ & Euph & 8.5 \\
\hline & 2 & Dipt & $18.9(7.2)$ & Sapo & $14.3(14.5)$ & & Myrt & $14.5(16.4)$ & Myrt & $10.5(10.6)$ & Dipt & 10.7 & Faga & 7.0 \\
\hline & 3 & Myrt & $15.4(17.6)$ & Dipt & $9.5(8.4)$ & & Faga & $11.6(13.0)$ & Laur & $9.2(9.3)$ & Burs & 9.0 & Burs & 6.6 \\
\hline & 4 & Burs & $14.6(16.7)$ & Euph & 9.5(9.6) & & Laur & $10.0(11.1)$ & Faga & $6.3(6.4)$ & Sapo & 6.6 & Meli & 5.8 \\
\hline & 5 & Sapo & $7.0(8.0)$ & Faga & $7.1(7.2)$ & & Euph & $7.0(7.9)$ & Sapo & $6.0(6.1)$ & Meli & 4.7 & Myrt & 5.6 \\
\hline & 6 & Euph & $3.8(4.4)$ & Burs & $6.0(6.0)$ & & Burs & $4.6(5.2)$ & Dipt & $5.0(4.0)$ & Euph & 4.6 & Dipt & 5.0 \\
\hline & 7 & Myri & $3.8(4.3)$ & Meli & $6.0(6.0)$ & & Sapo & $4.3(4.9)$ & Meli & $3.4(3.5)$ & Mora & 4.4 & Gutt & 3.8 \\
\hline & 8 & Meli & $3.7(4.2)$ & Myri & $3.6(3.6)$ & & Mora & $2.6(2.9)$ & Corn & $3.1(3.2)$ & Ster & 3.8 & Sapo & 3.8 \\
\hline & 9 & Cela & $3.6(4.1)$ & Cela & $2.4(2.4)$ & & Meli & $2.1(2.3)$ & Mora & $3.1(3.2)$ & Gutt & 3.8 & Sapi & 3.6 \\
\hline & 10 & Bomb & $1.3(1.5)$ & Elae & $2.4(2.4)$ & & Icac & $1.6(1.8)$ & Rubi & $2.6(2.7)$ & Myrt & 3.7 & Laur & 3.4 \\
\hline G600 & 1 & Faga & $\overline{13.0(13.5)}$ & Euph & $\overline{14.4(14.5)}$ & S600 & Dipt & $\overline{14.2(8.0)}$ & Laur & $\overline{9.7(9.7)}$ & & & & \\
\hline & 2 & Euph & $10.1(10.6)$ & Sapo & $6.7(6.8)$ & & Faga & $11.5(12.4)$ & Euph & $9.4(9.5)$ & & & & \\
\hline & 3 & Dipt & $9.5(5.5)$ & Laur & $6.2(6.3)$ & & Anac & $11.2(12.0)$ & Myrt & $8.6(8.7)$ & & & & \\
\hline & 4 & Mora & $6.9(7.2)$ & Mora & $5.1(5.2)$ & & Myrt & $9.8(10.4)$ & Faga & $8.2(8.3)$ & & & & \\
\hline & 5 & Sapi & $6.0(6.3)$ & Urti & $5.0(5.0)$ & & Laur & 7.3(7.7) & Sapo & $6.7(6.8)$ & & & & \\
\hline & 6 & Sapo & $5.2(5.5)$ & Meli & $4.5(4.5)$ & & Burs & $7.1(7.7)$ & Dipt & $6.2(5.4)$ & & & & \\
\hline & 7 & Anac & $4.8(5.0)$ & Sapi & $4.5(4.5)$ & & Sapo & $6.2(6.6)$ & Burs & $5.3(5.3)$ & & & & \\
\hline & 8 & Laur & $4.6(4.8)$ & Faga & $4.3(4.3)$ & & Euph & $4.9(5.2)$ & Anac & $4.2(4.2)$ & & & & \\
\hline & 9 & Meli & $3.5(3.7)$ & Dipt & $4.0(3.3)$ & & Gutt & $2.5(2.7)$ & Gutt & $3.9(3.9)$ & & & & \\
\hline & 10 & Myrt & $3.4(3.6)$ & Myrt & $3.8(3.8)$ & & Poly & $2.3(2.5)$ & Eben & $2.8(2.9)$ & & & & \\
\hline
\end{tabular}


its location at the borderline between the montane and lowland zones. We therefore defined S1000 as SFMF.

TWINSPAN analysis revealed a group consisting of G850-G990. Co-dominance of a few high elevation dipterocarp species and other representative montane families such as Fagaceae and Myrtaceae was a characteristic feature of this group. Emergent trees appeared from this altitudinal level. The low $P S$ between G600 and G850 suggests notable changes in species composition between these two altitudinal levels. G850-G990 corresponded well with "Upper hill dipterocarp forest" sense Wyatt-Smith in terms of the species composition of high elevation specific dipterocarp tree species as well as its physiognomy. G850-G990 were therefore named "Upper hill dipterocarp forest" (UHDF) after Wyatt-Smith, though these forests did not form a single cluster in the dendrogram. UHDF differed slightly from the hill area of the "Lowland zone" sense Kitayama in Mt. Kinabalu, which included lowland-hill specific dipterocarp trees. Laumonier documented similar vegetation in the lower part (lower than $1200 \mathrm{~m}$ asl) of the Sub-montane forest.

G600, S600 and S800 formed a single cluster. Representative lowland and montane families were codominant in each plot as in UHDF. G600 showed welldeveloped stratification as complex as in the lowlands, with frequent occurrence of emergent trees approaching $50 \mathrm{~m}$ in height. This emergent layer consisted of some Shorea species and Swintonia schwenkii. A number of hemi-epiphytic figs were also found in the emergent layer. S600 showed similar stand features as G600 but a lower stand height. G600 contained some lowland as well as hill dipterocarp species, while S600 contained upper hill specific and hill dipterocarp species but only one species of lowland dipterocarp. Hereby we named S600 UHDF and G600 "Mid-hill dipterocarp forest (MHDF)". S800 had no clear emergent layer and included upper hill specific dipterocarps but no lowland and hill specific species as in G850 and G990. It was categorized as UHDF.

The species composition and physiognomy of "Medium elevation hill forest" sense Laumonier was very similar to MHDF. MHDF also corresponded well with "Hill dipterocarp forest" in Malay Peninsular, especially in the coastal hill area, where Swintonia schwenkii and Shorea maxiwelliana (most of which had been previously logged in G600) were observed as the emergent layer. The floristic features of the hill region in the "Lowland zone" on Mt. Kinabalu were also similar. The floristic and physiognomical characteristics of MHDF were most similar to these 3 hill forest types; however, MHDF was clearly characterized by the high dominance of Fagaceae, Euphorbiaceae and Moraceae and lack of dominance of Dipterocarpaceae. This trait is thought to be the result of the regional climate and loggings impacts (Nishimura et al., 2006). These findings show that the structure of the altitudinal zonation of vegetation in Padang region is basically the same as that of other West Malesia regions at least within the altitudinal range of this study; that is, it consists of a lowland zone characterized by Dipterocarpaceae and montane zone co-dominated by Fagaceae, Myrtaceae and other characteristic montane families. However, in this study, the borderline between these two zones was not as clear as in the other regions examined. We therefore compared the dendrogram obtained for Padang region with one obtained for Mt. Kinabalu (Kitayama, 1992) (Fig. 4). The vegetation data for Mt. Kinabalu was subjected to cluster analysis according to the same method applied to the Padang data. In Mt. Kinabalu, lowland and montane zone plots were clearly separate and formed two distinct clusters. However, in Padang region, no distinct clusters were formed and the separation between lowland and montane plots was unclear (Fig. 4). We suspect that the lesser dominance of Dipterocarpaceae and relatively high dominance of representative montane families such as Fagaceae and Myrtaceae in the lowland zone cause this obscured border between the lowland and montane zones in the dendrogram.

\section{Critical altitude}

The basic structure of altitudinal zonation in this region was not far different from that in the other regions of West Malesia examined; however, the critical elevations of these zones and characteristic plant species were different. Dipterocarpaceae, the most important family in MHDF and UHDF, disappeared at higher altitudes with $\mathrm{WI} \geq 180{ }^{\circ} \mathrm{C} \cdot$ month. There was very low dominance of Dipterocarpaceae in S1000, and therefore, the estimated elevation showing $\mathrm{WI}=180{ }^{\circ} \mathrm{C} \cdot$ month, $1044 \mathrm{~m}$ asl, could be the critical border in Bukit Sibakaljawi. Though we could not determine the exact threshold in Gunung Gadut, the estimated altitude showing $\mathrm{WI}=180{ }^{\circ} \mathrm{C}$. month was $1079 \mathrm{~m}$, which is very similar to that in Bukit Sibakaljawi. Hereby we estimated the critical altitude between lowland and montane vegetation to be around $1050 \mathrm{~m}$ in this region.

Table 9 shows the large variation in the critical elevation of dipterocarps in West Malesia (Pendry \& Proctor, 1996 revised). Whitmore (1984) suggested that in South-east Asia only the huge mass of the New 
Table 9. Highest recorded of the occurrence of dipterocarpus on selected mountains in West Malesia based on Pendry \& Proctor (1996), and estimated critical elevation of dipterocarpus in this study.

\begin{tabular}{|c|c|c|c|c|c|}
\hline Geological region & Study site & $\begin{array}{l}\text { Summit } \\
\text { altitude } \\
\text { (m) }\end{array}$ & $\begin{array}{l}\text { Maximum } \\
\text { altitude for } \\
\text { dipterocarpus } \\
\text { (m) }\end{array}$ & Geoglaphy & Refference \\
\hline Borneo & Gunung Silam, Sabah & 884 & 700 & isolated coastal mountain & Proctor et al. (1988) \\
\hline Borneo & Bukit Belalong, Brunei & 913 & 880 & inland small mountain & Pendry \& Proctor (1996) \\
\hline Luzon & Mt. Maquiling, Luzon & 1055 & 600 & isolated inland mountain near a large lake & Brown (1919) after Pendory \& Proctor (1996) \\
\hline Malay Peninsular & Gunung Jelai, Kedah & 1200 & 870 & isolated coastal mountain & Kochummen (1982) \\
\hline Sumatra & Bukit Sibakaljawi, Padang & 1309 & 1044 & one peak of midst of a range & This study \\
\hline Sumatra & Gunung Gadut, Padang & 1859 & 1079 & one peak of midst of a range & This study \\
\hline Borneo & Gunung Mulu, Sarawak & 2376 & 1350 & large mountain in the midst of a range & Martin (1977) \\
\hline Borneo & Mt. Kinabalu, Sabah & 4101 & 1200 & large mountain in the midst of a range & Kitayama (1992) \\
\hline
\end{tabular}

Guinea cordillera and, to a lesser extent, the Barisan range of Sumatra were likely to show a substantial Massenerhebung effect. The Massenerhebung effect causes large mountain massifs, as a result of their huge mass and warming from exposure to intense radiation during cloudless periods, to raise the air temperature overlying them, enabling plants to extend their altitudinal ranges (Schröter, 1926 after Bruijnzeel, 1993; Steenis, 1962). Therefore, if the Massenerhebung effect was at work in this region, the critical elevation of dipterocarps would be higher and the altitudinal range of each vegetation zone would be wider than in the other regions examined. However, in Padang, the critical altitude of dipterocarps was 1044-1079 m, which is relatively lower than the critical altitudes in East Sumatra (1200 m, after Laumonier 1997), Malay Peninsular (1300 m asl, after Wyatt-Smith 1964) and Mt. Kinabalu, Borneo (1200 m, after Kitayama 1992). This suggests that rather than a positive Massenerhebung effect, negative factors causing cool temperatures more strongly affect the thermal conditions in this region. In other words, it is likely that the frequent cloud coverage limits solar radiation reaching the mountain mass, and moreover, that the frequent rainfall has a further cooling effect.

We also compared the border altitude between MHDF and UHDF with the vegetation of Mt. Kinabalu (Kitayama, 1992). The Mt. Kinabalu dendrogram showed a large gap of similarity between K1000 and the K600-K800 cluster within the hill range of the "Lowland zone" sense Kitayama (Fig. 4), suggesting the existence of a vegetation border between 800 and $1000 \mathrm{~m}$ asl. This border probably corresponds to the border between MHDF (G600) and UHDF (S600) in Padang. The WI value of the border is thought to be between the 209.6 ${ }^{\circ} \mathrm{C} \cdot$ month of $\mathrm{G} 600$ and $207.4{ }^{\circ} \mathrm{C} \cdot$ month of S600, around $208{ }^{\circ} \mathrm{C} \cdot$ month. The altitudes corresponding to this WI were around $660 \mathrm{~m}$ in Gunung Gadut and $600 \mathrm{~m}$ in Bukit Sibakaljawi, which roughly correspond to the WI at $900 \mathrm{~m}$ asl in Kinabalu (Fig. 3, Table 5). Thus, the border altitude between the two hill forests differed between Padang and Mt. Kinabalu by about $300 \mathrm{~m}$.

Low temperatures and the hyperhumid climate were shown to characterize the zonal structure in this region, the critical altitudes of which were lower than in other regions of west Malesia. This phenomenon could be explained by the "coastal proximity zonation effect" (Bush 1986), the compression of zonal structure in small coastal mountain areas (Table 9) through lowering of the cloud base as a result of an increase in atmospheric humidity. Although the Barisan range is a massive mountain range, a similar phenomenon could occur here because of the hyperhumid climate in this region.

ACKNOWLEDGEMENTS We thank the late Emeritus Professor Dr. Syunzo Kawamura (Kyoto University) and Emeritus Professor Dr. Ryoichi Ogushi (Kanazawa University), Professor Dr. Marlis Rahman (Former rector of Andalas University), and Dr. Amsir Bakar (Head of Sumatra Nature Study Center, Andalas University) for their cooperation in this study under the Field Biology Research and Training Project in Sumatra. We also thank Dr. Mamoru Kanzaki and his colleagues at Kyoto University for fruitful discussion; Dr. Kanehiro Kitayama for supplying us with his many articles; the staff of Herbarium Bogorience, especially Mr. Wardi and Mr. Agus, for supporting our identification work; and Mr. Irwan Jr., Mr. Edi, Mr. Maison, Mr. Nadi, Mr. Deswendri, Mr. Beni and Mr. Oki for supporting our field work. We especially thank Dr. P. S. Ashton for supporting our species identification work and providing helpful comments. This study was financially supported by the Japan International Cooperation Agency (1994-1997) and 
Nippon Life Insurance Foundation (1995).

\section{REFERENCES}

Ashton, P. S. 1982. Dipterocarpaceae. In: Van Steenis, C. G. G. J. (ed), Flora Malesiana. ser. I, 9, 237-552. Martinus Nijhoff Publisher, The Hague.

Bruijnzeel, L. A., Waterloo, M. J., Proctor, J., Kuiters, A. T. \& Kotterink, B. 1993. Hydrological observations in montane rainforests on Gunung Silam, Malaysia, with special reference to the 'Massenerhebung' effect. Journal of Ecology 81: 145-167.

Burgess, P. F. 1969. Ecological factors in hill and mountain forests of the States of Malaya. Malay Nat 22: 119-128.

Burtt Davy, J. 1938. The classification of tropical woody vegetation types. Imperial Forestry Institute, Oxford. Inst. Paper 13.

Bush, M. 1986. Some effects of physical processes on the redevelopment of the forests of Krakatau. In: Krakatoa Centenary Expedition 1983 Final Report. Bush, M., Jones, P. \& Richards, K. (eds.). University of Hull, Department of Geography Miscellaneous Series, 33: 57-76.

Hill, M. O. 1979. TWINSPAN. A FORTRAN program for arranging multivariate data in an ordered twoway table by classification of the individuals and attributes. Cornell Univ., Ithaca.

Hotta, M. 1986. Diversity and Dynamics of Plant Life in Sumatra. Forest ecosystem and speciation in wet tropical environments. Part 2. Sumatra Nature Study, Botany. Kyoto University.

Hotta, M. 1992. Useful woods in Ulu Gadut, West Sumatra. Tropics 1: 265-273

Hotta, M., Inoue, T. \& Koyama, N. 1989. Result of Sumatra Nature Study 1980-1989, Yasakashobo, Tokyo (in Japanese).

Kira, T. 1976. Terrestrial Ecosystems. Kyoritsu, Tokyo (in Japanese).

Kitayama, K. 1992. An altitudinal transect study of the vegetation on Mount Kinabalu, Borneo. Vegetatio 102: $149-171$.

Kochummen, K. M. 1982. Effect of elevation on vegetation on Gunung Jerai, Kedah. Research Pamphlet 87. Forest Research Institute Malaysia, Kepong.

Kohyama, T. \& Hotta, M. 1986. Growth analysis of Sumatran Monophyllaea, possessing only one leaf throughout perennial life. Plant Species Biology 1: 117-125.
Laumonier, Y. 1997. The Vegetation and Physiography of Sumatra, Kluwer Academic Publishers, Dordrecht.

Martin, P. J. 1977. The altitudinal zonation of Forests along the West Ridge of Gunung Mulu. Forest Department, Sarawak.

Nakashizuka, T., Zulkifli, Y. \& Rahim Nik, A. 1992. Altitudinal Zonation of Forest Communities in Selangor, Peninsular Malaysia. Journal of Tropical Forest Science 4: 233-244

National Astronomical Observatory 1999. Climate. In: Chronological Scientific Tables 1999. Tokyo.

Nishimura, S. Yoneda, T. Fjii, S. Mukhtar, E. Abe, H. \& Kanzaki, M. 2006. Factors influencing the floristic composition of a hill forest in West Sumatra. Tropics 15: $165-175$.

Ogino, K., Hotta, M., Rusjdj, T. \& Yoneda, T. 1984. Forest ecology of G. Gadut area. In: Forest Ecology and Flora of G. Gadut, West Sumatra. Sumatra Nature Study (Botany) (ed), 15-48. Kyoto University, Kyoto

Ohsawa, M. 1982. A vegetation study on Mt. Kerinci, Sumatra. Biological Science 34: 48-56 (in Japanese).

Ohsawa, M. 1995. The Montane Cloud Forest and Its Gradational Changes in Southeast Asia. In: Ecological Studies 110. Tropical Montane Cloud Forest. Hamilton, L. S., Juvik, J. O. \& Scatena, F. N. (eds), 254-265. Springer-Verlag, New York.

Ohsawa, M, Nainggolan, P. H. J., Tanaka, N \& Anwar, C. 1985. Altitudinal zonation of forest vegetation on Mount Kerinci, Sumatra: with comparisons to zonation in the temperate region of East Asia. Journal of Tropical Ecology 1: 193-216.

Pendry, C. A. \& Proctor, J. 1996. Altitudinal zonation of rain forest on Bukit Belalong, Brunei: soils, forest structure and floristics. Journal of Tropical Ecology 13: $221-241$

Proctor, J., Anderson, J. M., Chai, P \& Vallack, H. W. 1983. Ecological studies in four contrasting lowland rainforests in Gunung Mulu National Park, Sarawak. I. Forest environment, structure and floristics. Journal of Ecology 71: 237-260.

Proctor, J. Lee, Y. F. Langley, A. M. Munro, W. R. C. Nelson, T. 1988. Ecological studies on Gunung Silam, a small ultrabasic mountain in Sabah, Malaysia. I. Journal of Ecology 76: 320-340.

Richards, P. W. 1996. The Tropical Rain Forest (second edition). Cambridge University Press, Cambridge.

Steenis, C. G. G. J. V. 1962. The mountain flora of the Malaysian tropics. Endeavor 21: 183-193.

Symington, D. F. 1974. Forester's manual of dipterocarps. Malayan Foresters Records. 16, reprinted by the 
University of Malaya Press, Kuala Lumpur.

United States Department of Agriculture, Natural Resources Conservation Service. 1998. Keys to Soil Taxonomy. 8 th edition. Soil Survey Staff.

Whittaker, R. H. 1952. A study of summer foliage insect communities in the Great Smoky Mountains. Ecological Monographs 22: 6.

Whitmore, T. C. 1984. Tropical rain forests of the Far East. Second Edition. Clarendon Press, Oxford.

Wyatt-Smith, J. 1963. Malayan Forest Records. No. 23, Forest Research Institute Malaysia, Kepong.

Yoneda, T. 2004. The flora of Mt. Gadut, West Sumatra.

1. Photo list of plant specimens from Pinangpinang Baru Plot in a foot hill tropical rainforest. Kagoshima University, Kagoshima.

Received $3^{\text {rd }}$ Feb. 2005

Accepted $15^{\text {th }}$ Feb. 2006

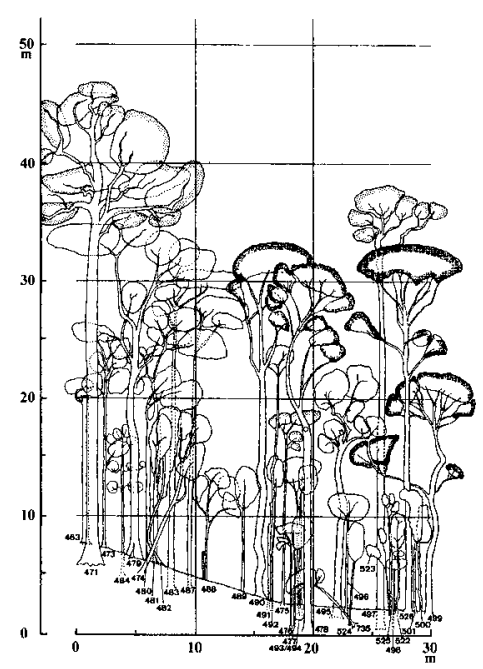

a: $\$ 600$

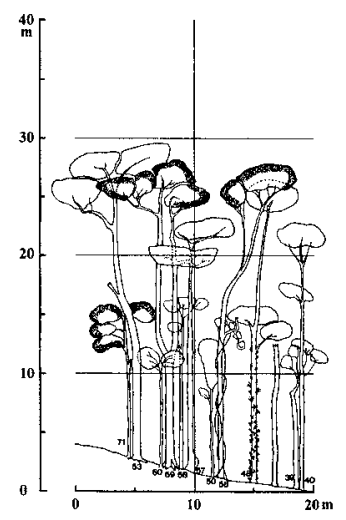

c: $\$ 1000$

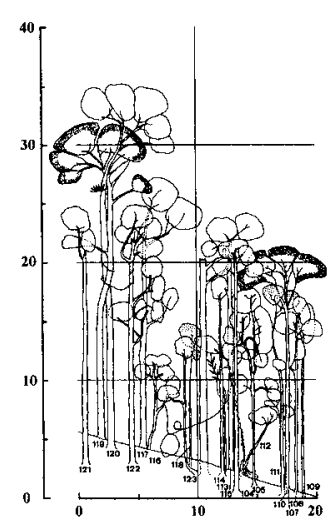

b: $\$ 800$

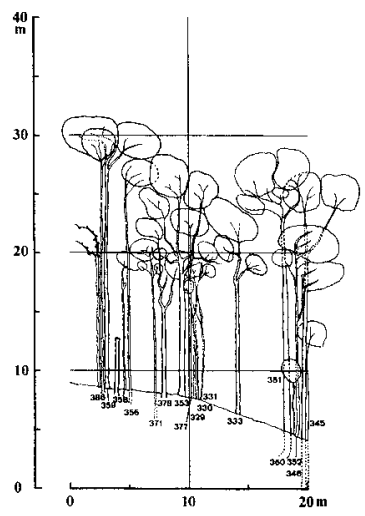

d: $\mathrm{G} 1280$
Appendix 1. Profile diagrams of 5 of the forest plots. a: $\mathbf{S 6 0 0 ,} b: S 800$, $c: S 1000$, d:G1280 and e: G1780. The profile of G600 is shown in Hotta et al. (1986). G850, G990 S1200 and G1600 were omitted. Trees with a dbh of less than $10 \mathrm{~cm}$ were excluded. In all profiles except $a$, the width of the area drawn is $10 \mathrm{~m}$; the width in a is $15 \mathrm{~m}$. Dark and light colored canopies indicate Fagaceae and Dipterocarpaceae canopy, respectively.

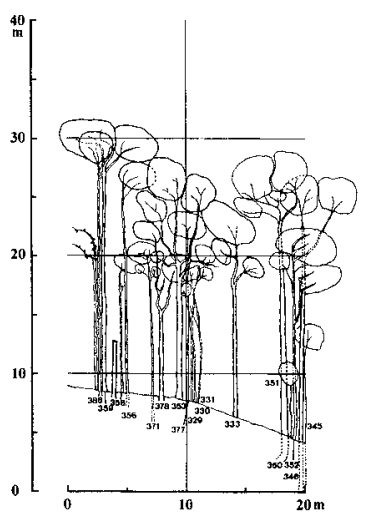

d: G1280 
Appendix 2. Species list of the forest diagram

\begin{tabular}{|c|c|c|}
\hline$\overline{\text { Tree No }}$ & Species & Family \\
\hline 463 & Litsea confusa & Lauraceaeaceae \\
\hline 471 & Shorea retinodes & Dipterocarpaceae \\
\hline 473 & Litsea confusa & Lauraceaeaceae \\
\hline 474 & Rhodamnia cinerea & Myrtaceae \\
\hline 475 & Vatica cf.perakensis & Dipterocarpaceae \\
\hline 476 & Artocarpus dadah & Moraceaeceae \\
\hline 477 & Santiria oblongifolia & Burseraceae \\
\hline 478 & Lithocarpus gracilis & Fagaceae \\
\hline 479 & Santiria laevigata & Burseraceae \\
\hline 480 & Eugenia confertum & Myrtaceae \\
\hline 481 & Alseodaphne falcata & Lauraceaeaceae \\
\hline 482 & Litsea confusa & Lauraceaeaceae \\
\hline 483 & Pentace triptera & Tiliaceae \\
\hline 484 & Eugenia attenuata & Myrtaceae \\
\hline 487 & Drypetes sp. & Euphorbiaceae \\
\hline 488 & Microcos florida & Tiliaceae \\
\hline 489 & Gymnacranthera forbesii varforbesii & Myristicaceae \\
\hline 490 & Quercus argentata & Fagaceae \\
\hline 491 & Mangifera swintonoides & Anacardiaceae \\
\hline 492 & Litsea confusa & Lauraceaeaceae \\
\hline 493 & Eugenia attenuata & Myrtaceae \\
\hline 494 & Garcinia rigida & Clusiaceae \\
\hline 495 & Eugenia besukiensis & Myrtaceae \\
\hline 496 & Pyrenarria serrata & Theaceae \\
\hline 497 & Shorea retinoides & Dipterocarpaceae \\
\hline 498 & Petunga microcarpa & Rubiaceae \\
\hline 499 & Quercus argentata & Fagaceae \\
\hline 500 & Mastixia trichotoma & Cornaceae \\
\hline 501 & Mesua conoidea & Clusiaceae \\
\hline 502 & Artocarpus nitidus var.griffithii & Moraceaeceae \\
\hline 522 & Macaranga lowii & Euphorbiaceae \\
\hline 523 & Memecylon myrsinoides & Melastomataceae \\
\hline 524 & Alangium javanicum & Alangiaceae \\
\hline 525 & Litsea diversifolia & Lauraceaeaceae \\
\hline 526 & Lithocarpus javensis & Fagaceae \\
\hline \multicolumn{3}{|l|}{ b. $\mathbf{S 8 0 0}$} \\
\hline Tree No & Species & Family \\
\hline 104 & Elaeocarpus obtusus & Elaeocarpaceae \\
\hline 105 & Knema mandaharan & Myristicaceae \\
\hline 107 & Lithocarpus javensis & Fagaceae \\
\hline 108 & Artocarpus nitidus var.griffithii & Moraceaeceae \\
\hline 109 & Pometia alnifolia & Sapindaceae \\
\hline 110 & Mastixia trichotoma & Cornaceae \\
\hline 111 & Shorea platyclados & Dipterocarpaceae \\
\hline 112 & ? & Burseraceae \\
\hline 113 & Ganua motleyana var.motleyana & Sapotaceae \\
\hline 114 & Schima noronhae & Theaceae \\
\hline 115 & Mesua catharinae & Clusiaceae \\
\hline 116 & Eugenia umbilicata & Myrtaceae \\
\hline 117 & Alseodaphne falcata & Lauraceaeaceae \\
\hline 118 & Shorea platyclados & Dipterocarpaceae \\
\hline 119 & Quercus argentata & Fagaceae \\
\hline 120 & ? & Lauraceaeaceae \\
\hline 121 & Cinnamomum subavenium & Lauraceaeaceae \\
\hline 122 & Nauclea subdita & Rubiaceae \\
\hline
\end{tabular}

\begin{tabular}{|c|c|c|}
\hline \multicolumn{3}{|l|}{ c. S1000 } \\
\hline Tree No & Species & Family \\
\hline 39 & Meliosma lepidota & Sabiaceae \\
\hline 40 & Litsea resinosa & Lauraceae \\
\hline 48 & Beilschmiedia lucidula & Lauraceae \\
\hline 50 & Memecylon myrsinoides & Melastomataceae \\
\hline 53 & Litsea firma & Lauraceae \\
\hline 56 & Quercus argentata & Fagaceae \\
\hline 57 & Atuna excelsa & Rosaceae \\
\hline 58 & Eugenia attenuata & Myrtaceae \\
\hline 59 & Lithocarpus benettii & Fagaceae \\
\hline 60 & Dysoxylum alliaceum & Meliaceae \\
\hline 71 & Quercus argentata & Fagaceae \\
\hline \multicolumn{3}{|l|}{ d. G1280 } \\
\hline Tree No & Species & Family \\
\hline 330 & Gonystylus macrophyllus & Thymelaceae \\
\hline 331 & Eugenia cerina & Myrtaceae \\
\hline 333 & Palaquium rostratum & Sapotaceae \\
\hline 345 & Palaquium pseudorostratum & Sapotaceae \\
\hline 346 & Ternstroemia aneura & Theaceae \\
\hline 350 & Chionanthus laxiflorus & Oleaceae \\
\hline 351 & ? & \\
\hline 352 & Ternstroemia aneura & Theaceae \\
\hline 353 & Garcinia rostrata & Guttiferae \\
\hline 358 & ? & \\
\hline 359 & ? & \\
\hline 371 & Cryptocarya nitens & Lauraceae \\
\hline 377 & Prismatomeris tetrandra & Rubiaceae \\
\hline 378 & Haemocharis integerrima & Theaceae \\
\hline 386 & Ardisia zollingerii & Myrsinaceae \\
\hline & Memecylon myrsinoides & Melastomataceae \\
\hline \multicolumn{3}{|l|}{ e. G1780 } \\
\hline Tree No & Species & Family \\
\hline 1 & Tetractomia obovata & Rutaceae \\
\hline 6 & Tetractomia obovata & Rutaceae \\
\hline 8 & Lithocarpus cf. lampadaria & Fagaceae \\
\hline 9 & Eribotrya bengalensis & Rosaceae \\
\hline 17 & Tetractomia obovata & Rutaceae \\
\hline 19 & Lithocarpus cf. lampadaria & Fagaceae \\
\hline 23 & $?$ & ? \\
\hline 24 & Eugenia leptantha & Myrtaceae \\
\hline 27 & ? & ? \\
\hline 97 & Elaeocarpus punctatus & Elaeocarpaceae \\
\hline 101 & ? & ? \\
\hline 102 & $?$ & ? \\
\hline 108 & Ternstroemia aff. Japonica & Theaceae \\
\hline 111 & Leptospermum flavescens & Myrtaceae \\
\hline 114 & Prunus arborea & Rosaceae \\
\hline 115 & Lithocarpus cf. lampadaria & Fagaceae \\
\hline
\end{tabular}

